\title{
Microbial Biodiversity of a Traditional Food Made from Squash Seeds "NTETE" Consumed in Brazzaville, Republic of Congo
}

\author{
Etienne Nguimbi ${ }^{1,2,3,}$, , Cyr Jonas Morabandza ${ }^{1}$, Alain Brice Vouidibio Mbozo ${ }^{1,4}$, \\ Mireille Huguette Belle Mbou ${ }^{1,3}$, Sayida Norgela Miakassissa ${ }^{1}$, Faly Armel Soloka Mabika ${ }^{1,2,3}$ \\ ${ }^{1}$ Molecular and Cellular Biology Laboratory, Faculty of Sciences et Technology, Marien Ngouabi University, Brazzaville, Republic of \\ Congo \\ ${ }^{2}$ Bioinformatics and molecular Biology Unit, Faculty of Sciences et Technology, Marien Ngouabi University, Brazzaville, Republic of Congo \\ ${ }^{3}$ Research Institute for Natural and Exact Sciences (IRSEN), Avenue de l'Auberge Gascogne Cité Scientifique (Ex. OROSTOM), \\ Brazzaville, Republic of Congo \\ ${ }^{4}$ Pluridisciplinary Food and Nutrition Research Team (EPRAN), Faculty of Sciences and Technology, Marien Ngouabi University, \\ Brazzaville, Republic of Congo
}

Email address:

etienne.ng1612@gmail.com (E. Nguimbi)

${ }^{*}$ Corresponding author

\section{To cite this article:}

Etienne Nguimbi, Cyr Jonas Morabandza, Alain Brice Vouidibio Mbozo, Mireille Huguette Belle Mbou, Sayida Norgela Miakassissa, Faly Armel Soloka Mabika. Microbial Biodiversity of a Traditional Food Made from Squash Seeds "NTETE" Consumed in Brazzaville, Republic of Congo. International Journal of Microbiology and Biotechnology. Vol. 5, No. 3, 2020, pp. 83-92. doi: 10.11648/j.ijmb.20200503.12

Received: May 8, 2020; Accepted: May 25, 2020; Published: June 9, 2020

\begin{abstract}
The microbial biodiversity of crushed, packaged and cooked (squash) squash seeds sold in Brazzaville markets for consumption has been explored. The enumeration and phenotypic characteristics of microorganisms, in particular: enterobacteria, yeasts, Bacillus, molds and coliforms were revealed, by conventional techniques of microbiology on specific media. The number of control samples not exposed to sale was compared with that of samples to be sold. Amplification by PCR of the $16 \mathrm{~S}$ rDNA of a few colonies taken from PCA was carried out, followed by sequencing and finally by a bioinformatic analysis on BLASTN. A phylogenetic inference test was carried out by MEGA. 7, preceded by multiple alignment of $16 \mathrm{~S}$ rRNA gene sequences. It appears from the count in the four markets chosen at random in Brazzaville that the total flora is variable: 101. $103 \mathrm{CFU} / \mathrm{g}$ for the Total market; 145. $103 \mathrm{CFU} / \mathrm{g}$ for the Bifouiti market; $140.103 \mathrm{CFU} / \mathrm{g}$ for the Talangai market and, 113,103 CFU / g for the Ouenzé market. However, the absence of coliforms was noted in all the samples. Control samples not exposed for sale show the absence of any microorganism. The morphotypes presented different characteristics according to the type and depending on each medium: on Mossel, the bacteria isolated were all Gram + , catalase positive, mobile, isolated or grouped in pair, with yellow, pink or, yellow-pink colonies. PCR revealed by electrophoresis on $0.8 \%$ agarose gel the amplified fragments of the 1500Sb rRNA gene of size $1500 \mathrm{bp}$. After sequencing, and analysis by BLASTN, the sequences were submitted to GenBank, the accession numbers are as follows: MK208500, MK208502, MK208503, MK208497, MK209069, MK209070. The alignment of the sequences obtained and their counterparts has revealed and confirmed that this gene is well conserved in the different genera with a very high similarity rate (97-100\%). The phylogenetic inference made it possible to have a coherent tree showing different monophyletic groups that are the different genera.
\end{abstract}

Keywords: Squash, Ntete, Microbial Biodiversity, PCR, Sequencing, Phylogenetic Inference 


\section{Introduction}

Squash is an ornamental and vegetable plant with a long climbing stem and large orange flowers, of which there are many cultivated forms. It is also a fruit of certain species of this plant, of various shape, size and color [1]. It belongs to the Cucurbitaceae family which includes about 100 genera and 750 species. This family is known for its great genetic diversity and its great adaptation to tropical, subtropical regions [2]. Cucurbits have been cultivated for a long time not only for nutrition but also for their medicinal properties. The squash is probably native to North America, and it is now cultivated everywhere $[3,4]$. The seeds of Cucurbita pepo and their oil have been the subject of several studies in the health field. Squash has many biological properties, such as anti-diabetic, antihypertension, anti-tumor, anti-bacterial, anti-inflammatory activities [5]. The seeds and their oils rich in monounsaturated and polyunsaturated fatty acids are used to relieve benign prostate disorders, the latter contain phytosterol compounds known for their health benefits [6].

Recently, special attention has been paid to the use of agricultural by-products, as well as co-products and waste from food processing [7]. In the food industry, many products and preparations based on squash are marketed, such as jams, syrups and also used as an additive in various products intended for our food. The squash has an interesting nutritional value. It has diuretic, laxative, sedative and anthelmintic properties; it is rich in carotene, contains almost $95 \%$ water, carbohydrates, calcium, iron vitamins A, B1, B2, B3, C, D, and E, as well as many trace elements. The composition per $100 \mathrm{~g}$ of squash was determined by [8].

With the development of local foods underway in the Congo, local foods, whether fermented or not, are being explored on a microbiological and biochemical level, with a view to mastering microbiological parameters for understanding the role of certain microorganisms. [9] presented a non-exhaustive list of local Congolese products and set out the prospects for biotechnological development from these foods for food safety and security. This is the case of fermented peppers explored by [10]. Cassava fermented leaves whose microbiological composition was given by [11], the presence of bacteria producing fibrinolytic enzymes in the fermented cassava leaves proven by [12], the predominance and role of bacteria of the genus Bacillus in these fermented cassava leaves clarified by $[13,14]$. The bacterial biodiversity of the fermented leaves of cassava evaluated by pyrosequencing 454 of the $16 \mathrm{~S}$ rRNA by [15]. The predominance of bacteria of the genus Bacillus in squash packed in the leaves and cooked presented by [1].

In the Republic of Congo, a food called "Ntété" is produced. This is made by crushed squash seeds, sometimes with crumbled salted or smoked fish, wrapped in leaves and then cooked. This food sold in different markets is widely consumed in Brazzaville. To our knowledge, the microbiological composition of these packed squashes is not known. It is in this perspective that this work studied the microbial biodiversity of this food, by counting the total flora and the different types of microorganisms on different specific environments. This work also compares the count on samples prepared for its own, therefore taken as control and those intended for sale, it identifies the causes of the presence of sometimes pathogenic germs in this food and suggests issues for a healthy food to the be consumed. This work has also identified some bacteria by amplifying by PCR and sequencing the gene coding for 16S rRNA. A phylogenetic classification test is proposed.

\section{Materials and Methods}

\subsection{Sites and Samples Collection}

In our study, the samples are represented by 8 packets of 'Ntete' (squash, squash, wrapped in leaves, then cooked) purchased from four targeted producers in four randomly selected markets in Brazzaville. In fact, in each market, each producer, after having crushed her pumpkin seeds packed on the leaves, cooks and leaves one of the packages under cover at home and takes other packages for sale. After a day of sales, we use two packages for each seller: one of the packages at home will be used as a witness during the count, while the package that went to the market, exposed for sale and to choice of buyers will be our sample to test, this to assess the degree of contamination generated by the day of sale. So each saleswoman always comes home, after her day of sale with a package that represents our sample. After collection, our samples were packed using sterile aluminum foil and placed in a cooler for transport to the laboratory. In the laboratory, part of each sample was taken directly for microbiological analyzes, if not temporarily stored at $4{ }^{\circ} \mathrm{C}$ for later analysis.

In Table 1 each site is represented by the name of the market where the sample was taken, each with a number, and also the different witnesses.

For a period of three months, we collected the samples three times for each producer, each time the collection was followed by the count, so that the results obtained repress the averages of the three counts.

Table 1. Sites and Collected samples.

\begin{tabular}{lllll}
\hline Sites & $\begin{array}{l}\text { Total } \\
\text { Market }\end{array}$ & $\begin{array}{l}\text { Bifouiti } \\
\text { Market }\end{array}$ & $\begin{array}{l}\text { Talangaï } \\
\text { Market }\end{array}$ & $\begin{array}{l}\text { Ouenzé } \\
\text { Market }\end{array}$ \\
\hline Samples & 1 & 2 & 3 & 4 \\
Controls & $\mathrm{T} 1$ & $\mathrm{~T} 2$ & $\mathrm{~T} 3$ & $\mathrm{~T} 4$ \\
\hline
\end{tabular}

The Figure 1 shows packages of squash "Ntete" with packaging (a) and without packaging (b).

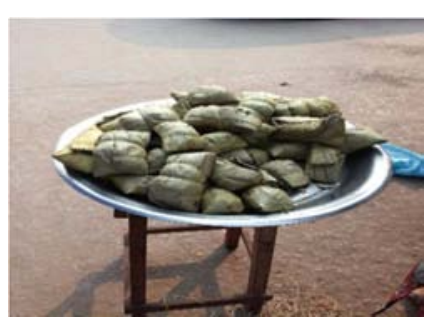

(a) 


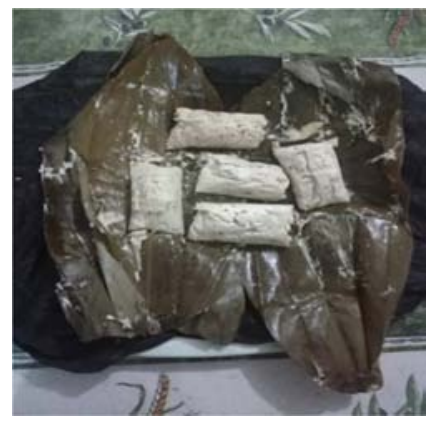

(b)

Figure 1. Showing packages of squash Ntete"with packaging (a) and without packaging (b).

\subsection{Culture Media and Counting}

For the microbial enumeration, the following culture media were used: PCA (Plate Count Agar) for the total flora, the EMB medium (Methylene Blue Eosin) for the enterobacteria, the Mossel medium for the Bacillus, the bengal pink Dichloran medium for yeasts, Purple Lactose Agar medium for coliforms, Sabouraud culture medium for yeasts and molds (or for fungal flora). The media were seeded with 100 microliters of the different dilutions at the rate of three petri dishes for each dilution. The culture conditions depending on each culture medium were respected. The colony count was carried out using Petri dishes carrying a significant number of colonies $(15 \mathrm{~N} \mathrm{~N} \leq$ 300) [16]. The bacterial counting was expressed in Colonyforming Units per gram (CFU / g), by applying the following formula $([17]$.

$$
\mathrm{UFC} / \mathrm{g}=\frac{\text { Colony number }}{\text { Dilution factor*used volume of culture }}
$$

To properly interpret the results, we calculated the means of each bacterial type by dividing the sum of the CFU by the number of dilutions performed. [16, 18].

\subsection{Isolation and Phenotypic Characterization of Microorganisms}

A few colonies were taken at random from PCA and Mossel media, these colonies were purified by three successive subcultures, then each isolate was subjected to phenotypic analysis.

The determination of the cultural characteristics (shape, relief and color of the colonies) was made by observation with a magnifying glass of the colonies obtained on the purification medium [19, 20]. The morphology of the bacterial cells (shape and arrangement) was assessed by microscopic observation of young cultures of $24 \mathrm{~h}$ in the fresh state $[21,22]$. This review also informed us about cell mobility. The Gram type of the isolates was determined by the $\mathrm{KOH}$ test: an isolated colony was emulsified in a drop of a $3 \% \mathrm{KOH}$ solution, obtaining a viscous and shooting suspension, indicates that the isolate is Gram negative [23]. The production of catalase was tested as described by [24]: an isolated colony was brought into contact with a fresh drop of hydrogen peroxide at 10 volumes. The presence of the enzyme results in the immediate appearance of an effervescence [24]. Finally, the sporulation test was carried out by subjecting the test strain to a thermal shock at $85^{\circ} \mathrm{C}$ for $10 \mathrm{~min}$ in a water bath, then replaced in the oven. Observation of growth after 24 to $72 \mathrm{~h}$ indicates that the strain is sporogenic. Growth $\mathrm{i}$ is also confirmed by microscopic observation.

\subsection{Molecular Identification of Some Isolated Bacteria}

It is based on the analysis of the rR16S gene, the different stages are the extraction of genomic DNA, the PCR amplification of the rR16S gene, the visualization of the PCR amplicons bands by Gel d' electrophoresis, sequencing, assembly and analysis by BLASTN.

\subsubsection{Extraction of Genomic DNA}

The extraction of genomic DNA by the NucleoSpin kit was carried out as indicated by the manufacturer. They were used by [1].

A new culture of the strain was suspended in $1 \mathrm{ml}$ of LB and centrifuged at 10,000 rpm for 4 minutes in the Micro Star 17R type. The collected cells were transferred to a Nucleo Spin Bead type bead tube and mixed with $100 \mu \mathrm{l}$ of BE elution buffer. To the suspension obtained, $40 \mu \mathrm{l}$ of $\mathrm{MG}$ buffer and $10 \mu \mathrm{l}$ of liquid proteinase $\mathrm{K}$ were added. Centrifugation was maintained at $10,000 \mathrm{rpm}$ for 1 minute. Then, 600 microliters of MG buffer added and vortexed for 3 seconds; the tubes were centrifuged at $10,000 \mathrm{rpm}$ for 1 minute. The supernatant was transferred to the column of Nucleo Spin microbial DNA placed in the collection of $2 \mathrm{ml}$ tubes, then centrifuged at $10,000 \mathrm{rpm}$ for 1 minute. The collection tube containing the collected liquid is discarded and the column of Nucleo Spin microbial DNA has been replaced in a new $2 \mathrm{ml}$ collection tube. The sample was washed twice: a first washing was carried out by adding 500 $\mu \mathrm{l}$ of BW buffer and the tubes were then centrifuged at $10,000 \mathrm{rpm}$ for 1 minute.

A second wash was carried out with $500 \mu$ of buffer B5 and the tubes were centrifuged at $10,000 \mathrm{rpm}$ for 1 minute, the collection tube containing the collected liquid was discarded and the column of Nucleo Spin microbial DNA was replaced in a new collection tube then centrifugation at $10,000 \mathrm{rpm}$ for 1 minute. The column of Nucleo Spin microbial DNA was placed in sterile Eppendorf tubes and $100 \mu \mathrm{l}$ of BE buffer were added, we then incubated at room temperature for 1 minute, after incubation, the tubes were centrifuged at 10,000 rpm for 1 minute. The DNA solution was collected.

\subsubsection{PCR Amplification of the 16S rRNA Gene}

\section{i. Primers Design and Synthesis}

The 16S rRNA gene is very conserved in prokaryotes, so it is often used to identify the different bacterial genera on the molecular level. There are universal primers for this purpose, we used those, already used by $[25,26]$. The sequences of the two primers are respectively: Forward F 5'-AGA GTT TGA 
TCC TGG CTC AG-3 'and Reverse R 5'-ACG GCT ACC TTG TTA CGA CTT-3'. The oligonucleotides were synthesized by the company Macogene France

ii. Preparation of the Mix and PCR Conditions

The PCR reaction was prepared in a final volume of 50 $\mu \mathrm{L}$, in a $200 \mu \mathrm{L}$ Eppendorf tube, containing $30 \mu \mathrm{L}$ of sterile distilled water, $2 \mu \mathrm{L}$ of DNA, $3 \mu \mathrm{L}$ of each sense and antisense primer, $1 \mu \mathrm{l}$ of dNTP, $10 \mu \mathrm{L}$ of the buffer. and $1 \mu \mathrm{L}$ of the Taq polymerase enzyme.

The PCR amplification was carried out in a GenAmp PCR system 2400 thermocycler (Perkin Elmer) according to the following steps:

a) initial denaturation at $95^{\circ} \mathrm{C}$ for $5 \mathrm{~min}$;

b) 30 cycles each of the cycle comprising: denaturation at $95^{\circ} \mathrm{C}$ for 40 seconds, hybridization at $56^{\circ} \mathrm{C}$ for 40 seconds, elongation at $72^{\circ} \mathrm{C}$ for 1 minute 20 seconds;

c) a final elongation at $72^{\circ} \mathrm{C}$ for 5 minutes.

\subsubsection{Agarose gel Electrophoresis of PCR Products}

Electrophoresis is a method of analysis, it separates DNA, 'RNA and proteins according to their molecular weight, their electrical charge and their configuration. In general, a gel is used. PCR products were visualized by $0.8 \%$ agarose gel electrophoresis. We used the TBE buffer (Tris-Borate-EDTA) $\mathrm{pH} 8.3$, the migration at 100 volts lasted one hour and we stained with BE for 20 minutes. A size marker was used to allow the revelation to distinguish the size of the bands of the obtained amplicons.

\subsubsection{Sequencing of PCR Products and Assembly of Sequences}

Sequencing was used by Macrogene France, briefly the PCR products for the 16S rRNA genes were purified using the NucleoFast 96 PCR plate (Macherey-Nagel EURL, France) and sequenced using terminator chemistry BigDye on an ABI3730 sequencer (Applied Biosystems, Foster City, California, United States). The sequencing was carried out by electrophoresis on a DNA analyzer 3730xl-Titania (Applied Biosystems) using the same primers. The assembly was carried out by Codon Code and DNA Baser. We proceeded as for [26].

\subsection{Analysis of the Results}

We used Microsoft Excell for graphs of statistical data on counts in different settings, and also for standard deviations from the average.

In the case of the biological sequences of the rR16S genes, we carried out a bioinformatics analysis. We first used BLAST nucleotides (BLASTN) from NCBI. The different request sequences have been submitted; the BLAST $N$ interface gave us the counterparts. By taking into account the percentages of similarity, the E. Values and the scores between counterparts of the database and the query sequences, we have based on the counterparts found the sequences equivalent to each query sequence. We have retained that for a percentage of similarity greater than or equal to $99 \%$, the isolate would be attributed to the species of the corresponding counterpart and if this percentage was between $97 \%$ and $99 \%$, the isolate would correspond to the genus.

We then used BIODITH to align the sequences and finally MEGA. 7 was used to infer the phylogenetic classification test of the different strains according to the 16S rRNA genes, the working methods were inspired by [27-29].

\section{Results and Discussion}

\subsection{Enumeration}

\subsubsection{Enumeration of the Total Flora}

It was evaluated on PCA medium for each of the four samples from the markets. Figure 2 represents the estimated quantification of the total flora on PCA medium. This figure shows that all of these samples contain microorganisms, but in different proportions. The total flora is more abundant in the sample from the Bifouiti market, followed by the sample from the Talangaï market, then in the sample from the Ouenzé market. It is low in the Total market sample. In contrast we found that in all control T1, T2, T3, and T4 the amounts of microorganisms are zero, no colony appears on the petri dishes. Using Excel, this does not appear thick in Figure 2.

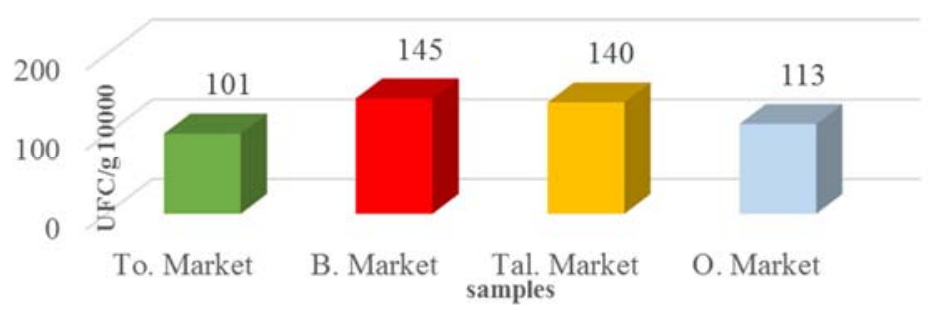

Figure 2. Enumeration of the total flora in CFU/g on the PCA medium, for the different samples of pumpkin seeds, cooked and bought in the four markets of Brazzaville.

To Market: Total market; B. Market: Bifouiti Market; Tal Market: Talangaï Market; O Market: Ouénzé Market

\subsubsection{Enumeration of the Different Types of Microorganisms}

Table 2 presents the quantification of the different types of microorganisms contained in the squash samples from the different markets used in our study. This table shows that all samples contain the following types of microorganisms: enterobacteria, Yeast, Bacillus and mold, but not all samples 
contain coliforms. The amount of type of microorganism varies for a sample from one market to another. For a given market, the quantity of a type of microorganism varies from one specific medium to another. The amount of microorganism in the different controls (T1, T2, T3 and T4) is zero.

Table 2. Quantification of the different types of microorganisms according to the specific medium.

\begin{tabular}{|c|c|c|c|c|c|c|c|c|}
\hline \multirow{3}{*}{ Milieux/Type } & \multicolumn{8}{|c|}{ Quantification des microorganismes en UFC/g. $10^{3}$ dans des échantillons des différents marchés } \\
\hline & \multicolumn{2}{|l|}{ Total } & \multicolumn{2}{|l|}{ Bifouiti } & \multicolumn{2}{|l|}{ Talangai } & \multicolumn{2}{|l|}{ Ouenzé } \\
\hline & Sample1 & T1 & Sample2 & T2 & Sample3 & T3 & Sample4 & T4 \\
\hline EMB/ entérobactéries & $57 \pm 0,02$ & 0 & $21 \pm 0,1$ & 0 & $22 \pm 0,12$ & 0 & $42 \pm 0,11$ & 0 \\
\hline Mossel/ Bacillus & $74 \pm 0,3$ & 0 & $70 \pm 0,12$ & 0 & $94 \pm 0,1$ & 0 & $72 \pm 0,1$ & 0 \\
\hline Sabouraud/Levures et moisissures & $101 \pm 0,2$ & 0 & $80 \pm 0,11$ & 0 & $40 \pm 0,01$ & 0 & $98 \pm 0,2$ & 0 \\
\hline Dichloran Rose Bengale/moisissures ou levures & $11 \pm 0,2$ & 0 & $10 \pm 0,2$ & 0 & $12 \pm 0,22$ & 0 & $14 \pm 0,21$ & 0 \\
\hline
\end{tabular}

\subsection{Phenotypic Characteristics of Isolates}

The morphological characteristics of the isolates related to the observation of colonies for each type of microorganism, Figure 3 (a) (b) (c) and (d) presents some aspects of colonies.

The biochemical characteristics revealed the presence of Gram +, Gram-, bacilli, coccis, and bacteria with catalase positive, mobile and immobile bacteria.

Table 3 presents the phenotypic characteristics of some isolates obtained on Mossel medium from squash on the Total market. Indeed, on Mossel medium the results are very similar in all markets on the morphological and biochemical plan: the isolates are Gram + , the colors of colonies are either yellow, or yellow-pink, or pink and the bacterial cells in the form of rods are either isolated or associated in pairs. All bacteria are catalase positive and mobile.

Table 3. Phenotypic characteristics of some isolates on Mossel medium obtained from squash on the Total market.

\begin{tabular}{|c|c|c|c|c|c|c|}
\hline Isolates & Colony forms and aspects & Colony colour & Cells arangment & Cells Mobility & Gram & Catalase \\
\hline IMT1 & Curved circular & Yellow & Isolated sticks & + & Gram+ & + \\
\hline IMT2 & Circulaire plane & Yellow pink & Sticks in pair & + & Gram+ & + \\
\hline IMT3 & Curved circular & Yellow & Isolated sticks & + & Gram+ & + \\
\hline IMT4 & Dentelé & Yellow & Isolated sticks & + & Gram+ & + \\
\hline IMT5 & Curved circular & Yellow pink & Isolated sticks and in pair & + & Gram+ & + \\
\hline IMT6 & Flat circular & pink yellow & Isolated sticks & + & Gram+ & + \\
\hline IMT8 & Flat circular & pink & Isolated sticks & + & Gram+ & + \\
\hline IMT9 & Flat circular & pink & Isolated sticks & + & Gram+ & + \\
\hline ST10 & Flat circular & Yellow & Isolated sticks & + & Gram+ & + \\
\hline
\end{tabular}

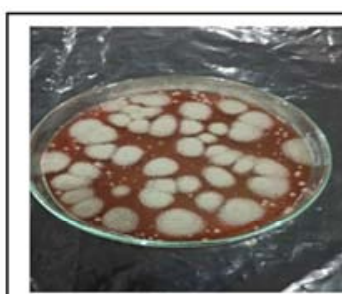

(a)

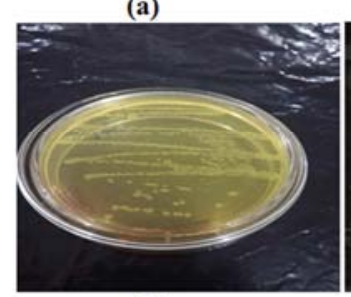

(c)

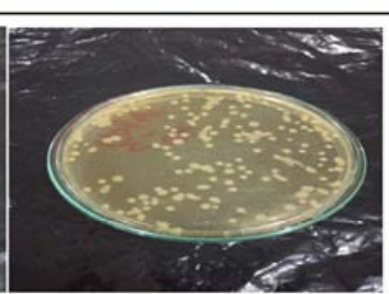

(b)

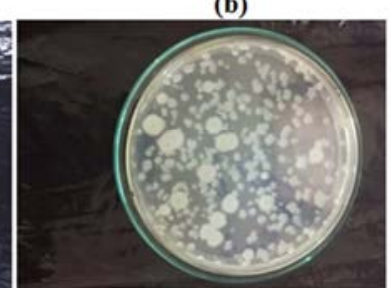

(d)
Figure 3. Morphotypes of some microorganisms counted in the squash samples.

(a): mold observed in squash on the Total market. (b): Yeasts observed in squash on the Talangai market. (c): Bacillus sp observes in squashes on the
Bifouiti market. (d): Colonies of microorganisms on PCA, ouenzé market.

\subsection{Molecular Identification of Isolates}

\subsubsection{Electrophoresis of PCR Products from Amplification of rRNA16s Genes from Isolates}

Figure 4 shows the electrophoretic profile of the PCR amplicons of rDNA16S on $0.8 \%$ of Agarose gel. The bands are approximately $1500 \mathrm{bp}$ in size. Only five of the six strains identified, of the two bacteria of the genus Burkolderia sp. only one is shown here.

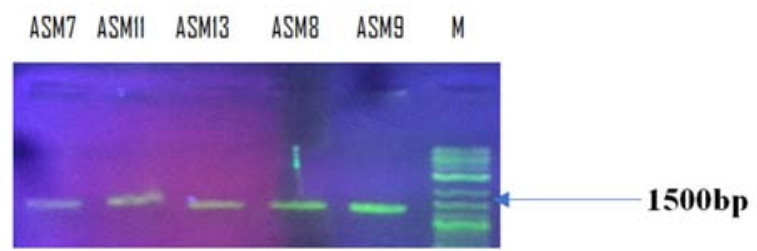

Figure 4. Electrophoresis on Agarose Gel at $0.8 \%$ of the PCR products of the rRNA16S gene of strains isolated from squashes seeds, on PCA medium, sample from the Total market. 
ASM7=Burkolderia cenocepacia, ASM11=Burkolderia seminalis, ASM13=Burkolderia $\quad$ sp., $\quad$ ASM8=Pseudomonas putida, ASM9=Staphylococcus haemolyticcus. M=standard molecular marker.

\subsubsection{Bioinformatic Analysis of $16 \mathrm{~S}$ rDNA Sequences and Phylogenetic Inference Test}

i. BLASTN Analysis and Sequences Submission in GenBank

The amplicons obtained by PCR were sequenced then, the assembled sequences, finally the six sequences were the subject of a bioinformatics analysis using the BLASTN tool.

Table 4. Accession numbers in GenBank of the sequences obtained for the identified strains.

\begin{tabular}{ll}
\hline $\begin{array}{l}\text { Numéros d'Accession dans } \\
\text { GENbank }\end{array}$ & Souches identifiées \\
\hline MK208500 & Burkolderia seminalis ASM11 \\
MK208502 & Burkolderia sp. ASM13 \\
MK208503 & Burkolderia sp. ASM14 \\
MK208497 & Burkolderia cenocepacia ASM7 \\
MK209069 & Pseudomonas putida ASM8 \\
MK209070 & Staphylococcus haemolyticcus ASM9 \\
\hline
\end{tabular}

Analysis by BLASTN made it possible to find the sequence correspondences as a function of the percentage of similarity, of E. value and of the scores for the six strains originating from the six colonies taken from PCA, as a function of the sequences of the homologous rR16S genes. in GenBank. Table 4 presents the strains identified by molecular biology techniques. There are Accession numbers given by GenBank after our submission. The strains found show diversity.

ii. Multiple Alignment of the Sequences Obtained and Their Homologs in the Databases

Figure 5 shows part of the multiple alignment of the sequences of bacteria isolated from squash and counterparts in databases according to different genera. We can note the very high conservation of the $16 \mathrm{~S}$ rRNA gene sequences in prokaryotes and the strong similarity at the genus level. A total of sixteen sequences are aligned, including eleven sequences of bacteria isolated from squash and five counterparts from databases.

\begin{abstract}
$510-520$
550

560
.$\ldots 1 \ldots$

GGCAAGCGTTGTCCGGAATTATTGGGCGTAAAGGCTCGCAGGCGGTTCTTAAGTCTGATGTGAAAGCCCCCGGCTCAAC

MK207434.1 Bacillus subtilis A MK207435.1 Bacillus pumilus AS MK207437.1 Bacillus megaterium UKK207436.1 Bacillus subtilis IIK193815.1 Bacillus subtilis IIK208497.1 Burkholderia cenoce UKK208500.1 Burkholderia semina MK208502.1 Burkholderia sp. AS MK208503.1 Burkholderia sp. AS MK209069.1 Staphylococcus haem MK209070.1 Pseudomonas putida MK418913.1 Burkholderia sp. st MH842736.1 Burkholderia semina KY810685.1 Burkholderia cenoce KX009746.1 Staphylococcus haem G0200822.1 Pseudomonas putida GCAAGCGTTGTCCGGAATTATTGGGCGTAAAGGGCTCGCAGGCGGTTTCTTAAGTCTGATGTGAAAGCCCCCGGCTCAACC GAATTATTGGGCGTAAAGCGCGCGCAGGCGGTTTCTTAAGTTGATGTGAAAGCCCACGGCTCAACCGTGGAGGGTCATTGG GCAAGCGTTGTCCGGAATTATTGGGCGTAAAGGGCTCGCAGGCGGTTTCTTAAGTCTGATGTGAAAGCCCCCGGCTCAACC GGTGGCAAGCGTTGTCCGGAATTATTGGGCGTAAAGGGCTCGCAGGCGGTTTCTTAAGTCTGATGTGAAAGCCCCCGGCTC CGCGGTAATACGTAGGGTGCAAGCGTTAATTCGGAATTACTGGGCGTAAAGGGTGCGCAGGCGGTTTGCTAAGTCCGATGI CCGCGGTAATACGTAGGGTGCAAGCGTTAATCGGAATTACTGGGCGTAAAGCGTGCGCAGGCGGTTTGCTAAGACCGATGT AGCCGCGGTAATACGTAGGGTGCAAGCGTTAATCGGAATTACTGGGCGTAAAGCGTGCGCAGGCGGTTTGCTAAGTCCGAT CCGCGGTAATACGTAGGGTGCAAGCGTTAATTCGGAATTACTGGGCGTAAAGGGTGCGCAGGCGGTTTGCTAAGTCCGATG TGGCAAGCGTTATCCGGAATTATGGGCGTAAAGCGCGCGTAGGCGGTTTCTTAAGTCTGATGTGAAAGCCCACGGCTCAAC GTGCCAGCAGCCGCGGTTAATACAGAGGGTGCAAGCGTTAATCGGAATTACTGGGCGTAAAGCGCGCGTAGGTGGTTCGTT TTAATCGGAATTACTGGGCGTAAAGCGTGCGCAGGCGGTTTGCTAAGACCGATGTGAAATCCCCGGGCTCAACCTGGGAAC CGCGGTAATACGTAGGGTGCAAGCGTTAATCGGAATTACTGGGCGTAAAGCGTGCGCAGGCGGTTTGCTAAGACCGATGTG AATTACTGGGCGTAAAGCGTGCGCAGGCGGTTTGCTAAGACCGATGTGAAATCCCCGGGCTCAACCTGGGAACTGCATTGG GGTAATACGTAGGTGGCAAGCGTTATCCGGAATTATTGGGCGTAAAGCGCGCGTAGGCGGTTTCTTAAGTCTGATGTGAAA AAGCGTTAATCGGAATTACTGGGCGTAAAGCGCGCGTAGGTGGTTCGTTAAGTTGGATGTGAAAGCCCCGGGCTCAACCTG
\end{abstract}

MIK207434.1 Bacillus subtilis A MK207435.1 Bacillus pumilus AS MK207437.1 Bacillus megaterium IIK207436.1 Bacillus subtilis IIK193815.1 Bacillus subtilis UK208497.1 Burkholderia cenoce IIK208500.1 Burkholderia semina MK208502.1 Burkholderia sp. AS MK208503.1 Burkholderia sp. AS MK209069.1 Staphylococcus haem MK209070.1 Pseudomonas putida MK418913.1 Burkholderia sp. st MH842736.1 Burkholderia semina KY810685.1 Burkholderia cenoce KX009746.1 Staphylococcus haen G0200822.1 Pseudomonas putida

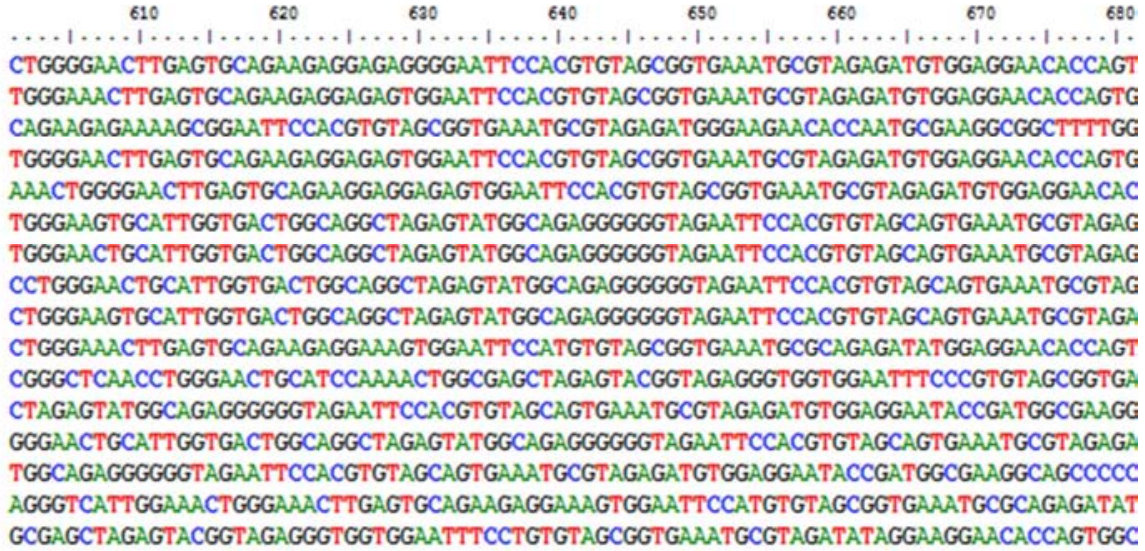

Figure 5. Part of the multiple alignment of sixteen sequences of which eleven come from squash and five are homologous sequences from the databases.

iii. Phylogenetic Classification of the Strains Identified by the Sequencing of $16 \mathrm{~S}$ rDNA

The phylogenetic classification of the bacteria isolated from the squash was made taking into account the six strains identified on the basis of the rR16S and the counterparts of the databases. In this phylogenetic inference, we have added strains of bacteria of the genus Bacillus also identified from squash samples and published in an earlier study by our laboratory.

Figure 6 shows the phylogenetic tree of bacteria isolated from squash and their counterparts from databases, the diversity of genera is clearly visible and the genera with monophyletic groups are also very distinct.

The evolutionary history was inferred using the UPGMA 
method [27]. The optimal tree with the sum of branch length $=0.52428865$ is shown. The tree is drawn to scale, with branch lengths in the same units as those of the evolutionary distances used to infer the phylogenetic tree. The evolutionary distances were computed using the Maximum Composite Likelihood method [28] and are in the units of the number of base substitutions per site. The analysis involved 16 nucleotide sequences. Codon positions included were $1 \mathrm{st}+2 \mathrm{nd}+3 \mathrm{rd}+$ Noncoding. All positions containing gaps and missing data were eliminated. There were a total of 1334 positions in the final dataset. Evolutionary analyses were conducted in MEGA7 [29].

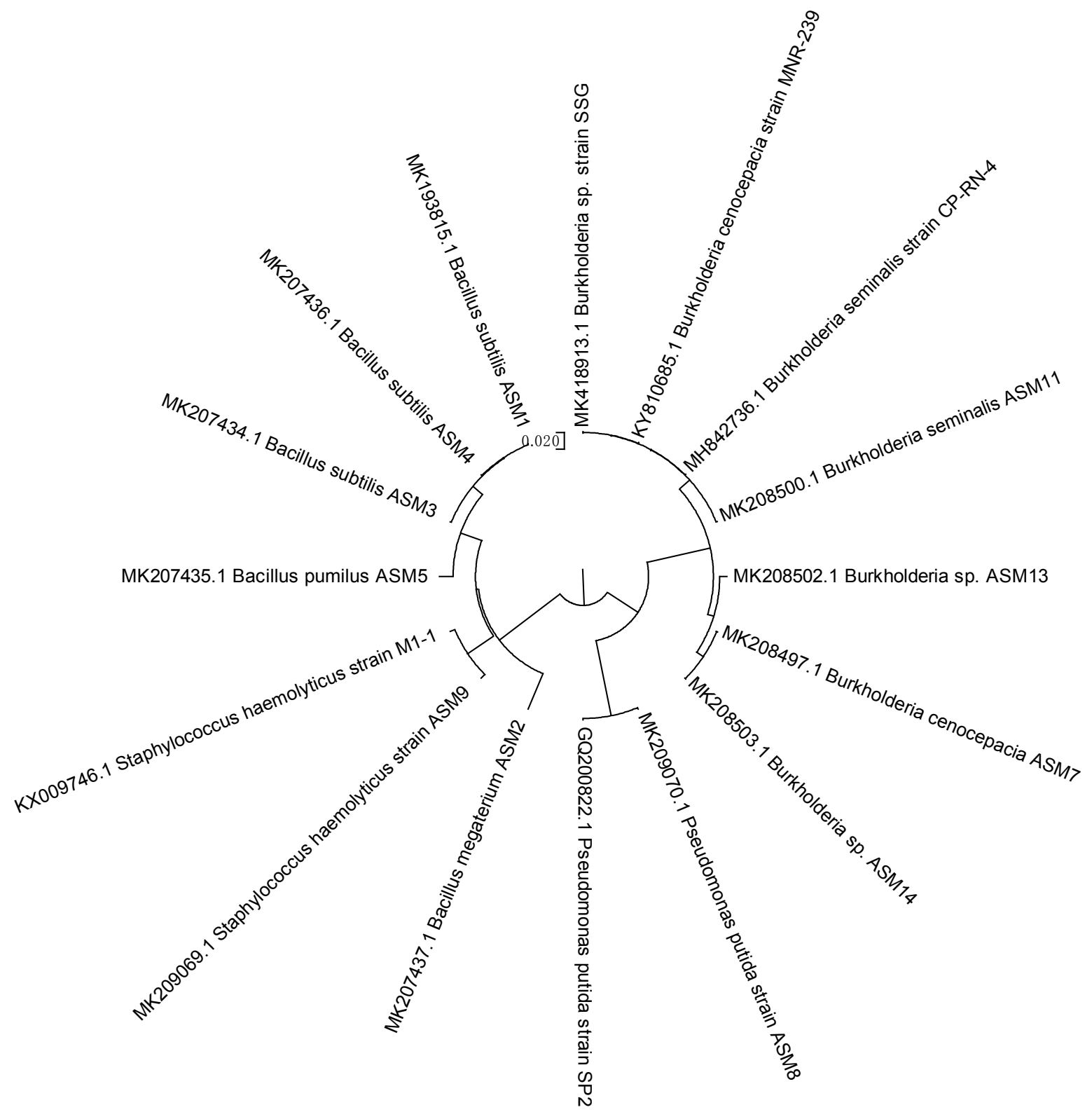

Figure 6. Phylogenetic tree showing the evolution relationships between different taxa using 16SrDNA at the level of bacteria isolated from squash and their database counterparts.

\section{Discussion}

The enumeration of microorganisms on the PCA medium shows that the amount of total flora varies from one sample to another, the values are between $\left(101.10^{3}\right.$ and $\left.145.10^{3}\right)$ CFU / g. The total flora is higher in the samples of the Bifouiti and Talangaï markets compared to the other two markets. These results are in harmony with those found by [15], working on fermented cassava leaves also when quantifying the total foreground show that the latter varied from one sample to another. This can be explained by the different environmental conditions of the places of manufacture of the various samples. On PCA medium, the number of microorganisms in all the controls is zero, this means that the squashes after their cooking do not contain microorganisms, this is understandable by the fact that during cooking the heat destroys any microorganism coming from any environment. In reality, the control sample that stays at home is free of any microorganisms. On the other hand, the sample which is submitted for sale on the market is exposed 
to the open air, handled by buyers who must make their choice. We admit that it is at this moment, when the squash becomes contaminated.

The enumeration of bacteria on different specific media demonstrates the presence of different genera in our food, the absence of coliforms can mean that our samples are free from contamination. However, the presence of enterobacteria counterbalances and forces us to look at ISO food standards in this direction. Certain samples could cause health risks for consumers. In specific environments, the various witnesses do not also show a microorganism, this confirms our hypothesis that the squash is contaminated during the sale. So for food safety, it is important to order squash from a targeted producer and have it delivered, or to get it dearly from the seller before it is exposed for sale. This would reduce the risk of contamination of these squashes.

We have highlighted the presence on the Mossel medium of bacteria of the genus Bacillus contained in the different samples of the seeds of crushed squash, packed on the cooked leaves intended for consumption. Our results show quantities between $\left(70.10^{3}\right.$ and $\left.94.10^{3}\right) \mathrm{CFU} / \mathrm{g}$. Several studies have shown that Bacillus can be isolated from food $[30,31]$. The results obtained show that bacteria of the genus Bacillus. [32] also showed that Bacillus sp would help reduce odors. These bacteria of the genus Bacillus presented the same characteristics, gram + , positive catalase, alone or combined in two and of characteristic colors. These morphotypes are identical to those described by [15].

Yeasts are present and molds too. In squash we can highlight a large number of types of microorganisms, certainly the interactions of these microorganisms are very important for the preservation and the organoleptic quality of this food. The microbial biodiversity of squash deserves another in-depth study to identify the roles of these different microorganisms in relation to their metabolism.

A recent study on crushed squash seeds, wrapped on leaves, cooked and ready for consumption has just highlighted the presence of bacteria of the genus Bacillus producing fibrinolytic enzymes [1].

Agarose gel electrophoresis for PCR amplification of the rRNA gene has given us fragments whose size is close to $1500 \mathrm{bp}$, this size has been approved by several studies which not only have shown the importance of this gene in the molecular characterization of eukaryotes, but also in the identification of the genus and the species. [33-35].

The identification by the $16 \mathrm{~S}$ rRNA gene allowed us to assess the diversity of squash bacteria, this diversity shows the presence of the following genera Burkolderia, Pseudomonas, Staphylococci and Bacillus. Indeed, the conserved regions of $16 \mathrm{~S}$ rDNA make it possible to define primers to amplify these genes in most microorganisms (choice of primers), while These variable regions are considered to be markers reflecting the phylogenetic relationships between organisms [36]. Our primers are universal primers, therefore chosen in very conserved areas. An exhaustive evaluation of the different samples would have increased the bacterial biodiversity. Our results join those of [10] worked on fermented chilli also used this gene for molecular identification, [37] already showed that this gene amplified by PCR was a good molecular marker in the identification of all bacterial genera. [26] used the rR16S gene sequencing to analyze the bacterial diversity of soils.

The presence of pathogenic germs in this food is not a danger to consumption, because of the different interactions between microorganisms which certainly annihilates their effects.

\section{Conclusion}

This study allowed us to explore the microbial biodiversity of squash seeds, crushed, wrapped on leaves and cooked for consumption; the presence of different bacterial genera makes it possible to speculate on the benefit of various interactions for the benefit of the consumer; However, a metagenomic study is fundamental to determine the dominant microorganisms, the enzymes present and the bacteria responsible for the production of these enzymes.

\section{Acknowledgements}

We would like to thank the managers of the Research Institute for Natural and Exact Sciences (IRSEN), we talk about the General Director Professor BOUKA BIONA and the Scientific Director Professor GOMA-TCHIMBKALA, for having made available not only their laboratory but also culture media.

\section{Conflicts of Interest}

Authors declare no conflict.

\section{References}

[1] Faly Armel Soloka Mabika, Etienne Nguimbi, Aimé Christian Kayath, and Gabriel Ahombo, "Molecular Characterization of Bacillus-Genus Bacteria with Fibrinolytic Potential Isolated from Squashes «NTETE» in Brazzaville in the Republic of Congo." American Journal of Microbiological Research, vol. 8, no. 1 (2020): 7-18. http://dx.doi.org/10.12691/ajmr-8-1-2.

[2] Giwa, E. O. and A. V. Ikujenlola, 2010. Quality characteristics of biscuit produced from composite flours of wheat and quality protein maize. Afr. J. Food Sci. Technol., 1: 116-119.

[3] Murkovic M., Mülleder U., Neunteufl H. (2002). Carotenoid content in different varieties of pumpkins. Journal of food composition and analysis. 15 (6): 633-638. https://doi.org/10.1006/jfca.2002.1052.

[4] Castilho, G. C., Aparecida, M. M., Kimura, M. (2007). Kinetics of osmotic dehydration and air-drying of pumpkins (Cucurbita moschata). Journal of Food Engineering. 82 (3): 284-291. https://doi.org/10.1016/j.jfoodeng.2007.02.004.

[5] Caili F., Huan S. et Quanhong L. (2006). A review on pharmacological Activities and Utilisation Technologies of pumpkin. Plant Foods for Human Nutrition. 61: 73-80.

[6] (Xanthopoulou, D., Bakker, A. B., Demerouti, E., \& 
Schaufeli, W. B. (2009). Work engagement and financial returns: A diary study on the role of job and personal resources. Journal of Occupational and Organizational Psychology, 82, 183-200.

[7] Compaore WR., Nikièma PA., Bassolé HIN., Savadogo A., Mouecoucou J., Hounhouigan DJ., Traoré SA. (2011). Chemical Composition and Antioxidative Properties of Seeds of Moringa oleifera and Pulps of Parkia biglobosa and Adansonia digitata Commonly used in Food Fortification in Burkina Faso. Curr Res J Biol Sci. Vol 3 (1): 64-72.

[8] (Adrian, R., R. Deneke, U. Mischke, R. Stellmacher, and P. Lederer. (1995). A long-term study of the Heiligensee (19751992): Evidence for effects of climatic change on thedynamics of eutrophied lake ecosystems. Arch. Hydrobiol. 133: 315337.

[9] Christian Aimé Kayath, Etienne Nguimbi, Joseph Goma Tchimbakala, Victor Mamonékéné, Augustin Aimé Lebonguy and Gabriel Ahombo (2016). Towards the Understanding of Fermented Food Biotechnology in Congo Brazzaville. Advance Journal of Food Science and Technology 12 (11): 593-602.

[10] Mokemiabeka nicaise Saturnin, Christian Aimé Kayath, Etienne Nguimbi, Aimé Augustin Lébonguy, Alfred Guy Macaire Eboungabeka, Ricardo De Mendosa, Simon Kéléké, Simon Charles Kobawila and Anne Botteaux (2016). Microbiological and biochemical assessment of crushed red pepper from Capsicum frutescens preserved in jars and manufactured in local markets in Republic of Congo. International Journal of Biotechnology Research Vol. 4 (1), pp. 001-010.

[11] Louembe, D., S. C. Kobawila, G. Bouanga Kalou and S. Kéléké, 2003. Etude microbiologique des feuilles fermentées de manioc: "Ntoba Mbodi". Tropicultura, 21 (3): 106-111.

[12] Nguimbi E., Ahombo G., Moyen R., Ampa R., Vouidibio A., Ontsira E. N., Kobawila S. C., Louembe D.(2014) " Optimization of growth, fibrinolytic enzyme production and PCR amplification of encoding fibrinolytic enzyme gene in bacillus amyloliquefaciens isolated from ntoba mbodi at Brazzaville ». International Journal of Science and Research;: 3 (358): 2799-2803.

[13] Alain Brice Mbozo Vouidibio, Christian Aimé Kayath, Etienne Nguimbi, Augustin Aimé Lebonguy and Simon Charles Kobawila (2017). Potential Spore-Forming Probiotics Isolated from Ntoba mbodi, Alkaline Fermented Leaves of Cassava from the Republic of the Congo. International Journal of Science and Research. Volume 6 Issue 1. 23197064.

[14] Faly Armel Soloka Mabika, Etienne Nguimbi, Raoul Ampa1, Aime Christian Kayath, Alain Vouidibio, Gabriel Ahombo (2018). Production, Encoding Genes Variability and NTerminal Sequences of Fibrinolytic Enzymes Produced by Bacillus Strains Isolated from Fermented Cassava Leaves "Ntoba Mbodi" at Brazzaville, Republic of Congo. International Journal of Science and Research (IJSR) Volume 7 Issue 11. p 241-248.

[15] Didine Priscilla Moutou-Tchitoula, Etienne Nguimbi, Stéphanie Giusti-Miller, Philippe Mora, Simon Charles Kobawila, Edouard Miambi* (2018). Assessment of dominant bacterial strains isolated from Ntoba mbodi, an indigenous African alkaline-fermented food, and their potential enzyme activities) African Journal of Microbiology Research, Vol. 12
(32), pp. 779-787, 28.

[16] Rodier J. et al., 2009-L'analyse de l'eau. 9eme édition entièrement mise à jour, Dunod paris, 1526 .

[17] DAUGA C., Doré J., Sghir A., 2005 La diversité insoupçonnée du monde microbien. médecine/Sciences, 3 (21):290-296.

[18] Coulybaly K., 2005-Etude de la qualité physico-chimique et bactériologique des puits de certains quartiers du district de Bamako. Thèse pour obtenir le grade de docteur en pharmacie (Diplôme d'Etat), Faculté de Médecine, de pharmacie Et d'Odontostomatologie Bamako (Mali), 69p.

[19] Dechache A. et Mofradj Z. (2014). Contribution à l'étude de conservation d'une souche de lactocoques isolée à partir du lait caprin. Mémoire de Master. Université d'Ouargla.p58.

[20] Alphonse M.; José D.; Alain B. (2004). Cours de microbiologie générale: avec problèmes et exercices corrigés, Editions Doin, 430 pages.

[21] Joffin JN, Leyral G. 1996 Microbiologie et technique. Centre Régional de Documentation Pédagogique d'Aquitaine, Bordeaux, France:219-223.

[22] Siboukeur A. (2011). Etude de l'activité antibactérienne des bactériocines (type nisine) produites par Lactococcus lactis sub sp lactis, isolée à partir du lait camelin. Thème de Magistère. Université Kasdi Merbah-Ouargla, 113p.

[23] Marshal, N., et Bourdon J. L. (1982) Les milieux de cultures pour l'isolement et l'identification biochimique des bacteries. Ed. Doin. Paris 1982.

[24] Larpent JP, M. L-G. Memento technique de Microbiologie. Lavoisier, Paris 1990.

[25] Weisburg W. G., Barns S. M., Pelletier D. A., Lane D. J. 16S ribosomal DNA amplification for phylogenetic study. J. Bacteriol, 1991; 173: 697-703.

[26] Ngo-Itsouhou, Nguimbi Etienne, Kayath Aimé Christian and Ampa Raoul. (2019) Molecular Identification, Phylogenetic Classification and Proteolytic Capacity of Cultivable Bacteria Isolated from Soils in Brazzaville, Republic of Congo. Journal of Biochemistry, Microbiology and Biotechnology Vol 7, No $2,1-7$.

[27] Sneath P. H. A. and Sokal R. R. (1973). Numerical Taxonomy. Freeman, San Francisco.

[28] Tamura K., Nei M., and Kumar S. (2004). Prospects for inferring very large phylogenies by using the neighbor-joining method. Proceedings of the National Academy of Sciences (USA) 101:11030-11035.

[29] Kumar S., Stecher G., and Tamura K. (2016). MEGA7: Molecular Evolutionary Genetics Analysis version 7.0 for bigger datasets. Molecular Biology and Evolution 33:18701874 .

[30] Schallmeys, M., Singh, A., \& Ward, O. P. (2004). Developments in the use of Bacillus species for industrial production.. Canadian Journal of Micrbiology, 50: 1-17).

[31] Bravo, A., Gomez, I., Porta, H., Gomez-Garcia, I. B., Rodriguez-Almazan, C., Pardo, L., et al. (2013). evolution of Bacillus thuringiensis Cry toxins insecticidal activity. Microb Biotechnol, 17-26. 
[32] Henshan E; E; Ikopoh IS., 2010. Effet of single bacteria star culture on odeur reduction during controlled fermentation of cassava tubers for foofoo production Malaysian journal of Microbiology, 6 (1) 57-61.

[33] Mohamed, M., Saeys, Y., Leys, N., Raes, J., and Monsieurs, P. (2015) CATCh, an ensemble classifier for chimera detection in $16 \mathrm{~S}$ rRNA sequencing studies. Applied and Environmental Microbiology 81 (5):1573-1584. doi: 10.1128/AEM.0289614.

[34] Poirier S, Rué O, Peguilhan R, et al. (2018) Deciphering intraspecies bacterial diversity of meat and seafood spoilage microbiota using gyrB amplicon sequencing: A comparative analysis with $16 \mathrm{~S}$ rDNA V3-V4 amplicon sequencing. PLOS ONE 13: e0204629. doi: 10.1371/journal.pone.0204629.
[35] Kim M, Oh H-S, Park S-C, Chun J (2014) Towards a taxonomic coherence between average nucleotide identity and 16S rRNA gene sequence similarity for species demarcation of prokaryotes. International Journal of Systematic and Evolutionary Microbiology 64:346-351. doi: 10.1099/ijs.0.059774-0.

[36] C. R. Woese, O. Kandler, and M. L. Wheelis. 1990. Towards a natural system of organisms: Proposal for the domains Archaea, Bacteria, and Eucarya. Proceedings of the National Academy of Sciences 87:4576-4579.

[37] Etienne Nguimbi, Yue-zhong Li, Bei-le Gao, Zhi-feng Li, Bing Wang, Zhi-hong Wu, Bai-xu Yan, Yin-boQu, and PeijiGao (2003). 16S-23S. Ribosomal DNA Intergenic Spacer Regions in Cellulolytic Myxobacteria and differentiation of closely related strains. System. Appl. Microbiol. 26, 262-268. 